\title{
Article/Artigo
}

\section{Hepatitis B virus genotyping among chronic hepatitis B patients with resistance to treatment with lamivudine in the City of Ribeirão Preto, State of São Paulo}

\author{
Genotipagem do vírus da hepatite B de pacientes crônicos com resistência ao tratamento com \\ lamivudina na Cidade de Ribeirão Preto, Estado de São Paulo
}

Rodrigo Haddad ${ }^{1}$, Ana de Lourdes Candolo Martinelli ${ }^{2}$, Sérgio Akira Uyemura ${ }^{3}$ and Jonny Yokosawa ${ }^{3}$

\begin{abstract}
Introduction: Lamivudine is a nucleoside analogue that is used clinically for treating chronic hepatitis B infection. However, the main problem with prolonged use of lamivudine is the development of viral resistance to the treatment. Mutations in the YMDD motif of the hepatitis $\mathrm{B}$ virus DNA polymerase gene have been associated with resistance to drug therapy. So far, there have not been many studies in Brazil reporting on genotype-dependent development of resistance to lamivudine. Thus, the aim of the present study was to determine the possible correlation between a certain genotype and increased development of resistance to lamivudine among chronic hepatitis B patients. Methods: HBV DNA in samples from 50 patients under lamivudine treatment was amplified by means of conventional PCR. Samples were collected at Hospital das Clínicas, FMRP-USP. The products were then sequenced and phylogenetic analysis was performed. Results: Phylogenetic analysis revealed that $29(58 \%)$ patients were infected with genotype D, 20 (40\%) with genotype A and one (2\%) with genotype F. Mutations in the YMDD motif occurred in $20 \%$ of the patients with genotype A and $27.6 \%$ of the patients with genotype D. Conclusions: Despite the small number of samples, our results indicated that mutations in the YMDD motif were 1.38 times more frequent in genotype $\mathrm{D}$ than in genotype $\mathrm{A}$.
\end{abstract}

Key-words: Hepatitis B. Lamivudine. YMDD. HBV genotype.

\section{RESUMO}

Introdução: Lamivudina é um análogo de nucleosídeo clinicamente utilizado para o tratamento da infecção crônica pela hepatite B. Entretanto, o principal problema do uso prolongado da lamivudina é o desenvolvimento de resistência viral ao tratamento. Mutações no motivo YMDD no gene da DNA polimerase do vírus da hepatite B estão associados com a resistência a terapia medicamentosa. Até o presente momento, não há muitos estudos no Brasil que descrevem o desenvolvimento genótipo-dependente da resistência à lamivudina. Assim, o intuito do trabalho aqui descrito foi determinar a possível correlação entre um determinado genótipo e o desenvolvimento aumentado da resistência à lamivudina em pacientes com hepatite $B$ crônica. Métodos: O HBV DNA foi amplificado por PCR convencional a partir de 50 amostras coletadas de pacientes submetidos ao tratamento com lamivudina no Hospital das Clínicas- FMRP- USP. Posteriormente, os produtos foram seqüenciados e a análise filogenética foi realizada. Resultados: A análise filogenética mostrou que 29 (58\%) pacientes foram infectados com o genótipo D, 20 (40\%) com o genótipo A e 1 (2\%) com o genótipo F. Mutações no motivo YMDD ocorreu em $20 \%$ dos pacientes com genótipo Ae 27,6\% em pacientes do genótipo D. Conclusões: Apesar do baixo número de amostras, nossos resultados indicaram que mutações no motivo YMDD são 1,38 X mais frequentes no genótipo $\mathrm{D}$ em relação ao genótipo $\mathrm{A}$.

Palavras-chaves: Hepatite B. Lamivudina. YMDD. Genótipo do HBV.

1. Regional Blood Center of Ribeirão Preto, Ribeirão Preto, SP. 2. Department of Clinical Medicine, Faculty of Medicine of Ribeirão Preto, University of São Paulo, Ribeirão Preto, SP. 3. Department of Clinical Analysis, Toxicology and Bromatology, Faculty of Pharmaceutical Sciences of Ribeirão Preto, University of São Paulo, Ribeirão Preto, SP.

Address to: Dr. Rodrigo Haddad. Fundação Hemocentro de Ribeirão Preto. Rua Tenente Catão Roxo 2501, 14051-140 Ribeirão Preto, SP.

Tel: 55 16 2101-9300; extension 9606;Fax: 55 16 2101-9309

e-mail: rodrigohaddad@hemocentro.fmrp.usp.br

Received in 29/10/2009

Accepted in 10/12/2009

\section{INTRODUCTION}

Hepatitis B is a public health problem of worldwide importance. Approximately 350 million people are chronic carriers and one third of the world's population has been in contact with the hepatitis B virus $(\mathrm{HBV})^{1}$. Chronic carriers are exposed to the development of complications arising from hepatitis $B$ infection, resulting in cirrhosis, hepatocellular carcinoma, liver failure or death ${ }^{2,3}$.

$\mathrm{HBV}$ is an enveloped virus that belongs to the Hepadnaviridae family. The viral genome consists of partially double-stranded circular DNA of approximately 3,200 base pairs $^{4}$. It codes for the small $(\mathrm{S})$, medium $(\mathrm{M})$ and large $(\mathrm{L})$ surface antigens (HBsAg), the core protein ( $\mathrm{HBcAg}$ ), a soluble core protein $(\mathrm{HBeAg})$, a protein of unknown function $(\mathrm{X})$ and the viral polymerase. Although $\mathrm{HBV}$ is a DNA virus, a genomic RNA strand is reverse transcribed into DNA by the viral polymerase during the viral replication cycle. This enzyme does not have proofreading repair activity, and this leads to potential errors during reverse transcription.

Chronic infection may be associated with high or low levels of viral replication, and with severe or absent inflammatory response in the liver. When the inflammatory response is absent or mild, antiviral therapy is not indicated ${ }^{5}$. Treatment is indicated in $\mathrm{HBsAg}$-positive patients with compensated liver disease who are either $\mathrm{HBeAg}$ positive or $\mathrm{HBeAg}$ negative and who have serum alanine aminotransferase (ALT) levels greater than or equal to twice the upper limit of normal and HBV DNA levels $\left(>10^{5} \text { copies } / \mathrm{ml}\right)^{6}$.

The aims of treatment in chronic hepatitis B cases are to achieve sustained suppression of HBV replication and remission of the liver disease. The endpoints used to assess treatment response include normalization of serum ALT level, undetectable serum HBV DNA in a non-amplifying assay, loss of $\mathrm{HBeAg}$ with or without detection of anti-HBe antibodies, and improvement in liver histology ${ }^{7}$. 
Interferon- $\alpha$ (INF- $\alpha$ ) was the only available therapeutic option for chronic hepatitis B until a few years ago. However, the efficacy of IFN- $\alpha$ was rather limited ${ }^{8}$. The development of nucleoside analogues has been a major advance in hepatitis B treatment. Some nucleoside analogues have excellent oral availability, a good safety record and antiviral efficacy comparable to that observed with interferon- $\alpha 2 b^{9}$.

Lamivudine, also known in the literature as (-)SddC, (-)BCH189 and (-)3TC, is the minus enantiomer of $\beta$-L-2', $3^{\prime}$-dideoxi-3' thiacytidine ${ }^{10}$. It is an oral cytosine nucleoside analogue that is clinically used for treating chronic HBV infection. It potently inhibits HBV replication by interfering with the reverse transcriptase activity of the viral polymerase, which results in a marked decrease of HBV DNA and ALT levels, seroconversion of $\mathrm{HBe}$ Ag to anti-HBe, and histopathological improvement ${ }^{11}$. However, one major problem with long-term use of lamivudine is the potential development of viral resistance, associated with increases in HBV DNA and serum transaminases ${ }^{12}$. The incidence of drug-resistant hepatitis B virus during lamivudine treatment is 14-36\% after one year of treatment and increases to $38 \%, 49 \%$ and $66 \%$ after two, three and four years of treatment, respectively ${ }^{13}$.

In most patients with lamivudine resistance, substitutions of the amino acid methionine at position 204 in the YMDD motif of the viral polymerase by either valine (M204V, YVDD) or isoleucine (M204I, YIDD) have been reported ${ }^{14}$. The mutation M204V is the most common and is accompanied by the leucine-to-methionine substitution at amino acid position 180 (L180M).

Eight hepatitis B virus genotypes have been recognized (A-G) $)^{15-18}$. Brazil is a country geographically divided into several regions that have been colonized by people of different ethnic backgrounds. Therefore, $\mathrm{HBV}$ genotype distribution may differ in these regions ${ }^{19}$. The genotypes $\mathrm{A}, \mathrm{D}$ and $\mathrm{F}$ are the most prevalent ${ }^{20-22}$, but genotypes $\mathrm{C}$ and $\mathrm{G}$ have also been reported ${ }^{23,24}$. In addition, there have been few studies describing the genotype-dependent development of resistance to lamivudine in $\mathrm{HBV}^{11}$.

The main objective of the present study was to determine the possible genotype-dependency related to the development of resistance to lamivudine among chronic hepatitis B patients treated at Hospital das Clínicas of Ribeirão Preto, University of São Paulo, in southeastern Brazil.

\section{METHODS}

\section{Clinical samples}

Serum samples were collected from 50 patients (Table 1) who had chronic hepatitis $B$ and received lamivudine therapy. The samples were obtained at the Gastroenterology Department of Hospital das Clínicas de Ribeirão Preto, Ribeirão Preto School of Medicine, University of São Paulo. These samples were grouped according to the following parameters: (1) regarding patients who responded to therapy, samples were collected before the treatment, and regarding patients whose response to therapy could not be determined because of lack of follow-up, the last sample that was collected was used; (2) regarding patients who did not respond to therapy, serum samples were collected either during or after the treatment.

\section{HBV DNA extraction, PCR amplification and purification}

HBV DNA was extracted from $200 \mu$ l of serum samples using the MasterPure ${ }^{\mathrm{TM}}$ Complete DNA and RNA Purification Kit (EPICENTRE ${ }^{\circledR}$ Biotechnologies. Madison, WI, USA), in accordance with the manufacturer's instructions. Part of the polymerase gene
TABLE 1 - Patients` features.

\begin{tabular}{lcccc}
\hline & \multicolumn{4}{c}{ Response to therapy } \\
\cline { 2 - 5 } Treatment months & yes (n) & no (n) & und. $^{*}(\mathrm{n})$ & Total \\
\hline 01 to 06 & 06 & 01 & 02 & 09 \\
07 to 12 & 07 & 04 & 00 & 11 \\
13 to 18 & 03 & 05 & 01 & 09 \\
18 to 24 & 03 & 04 & 01 & 08 \\
More than 24 & 07 & 06 & 00 & 13 \\
\hline Total & $\mathbf{2 6}$ & $\mathbf{2 0}$ & $\mathbf{0 4}$ & $\mathbf{5 0}$ \\
\hline
\end{tabular}

${ }^{*}$ Undetermined: patients that not have data to determine the DNA HBV levels.

(positions 55 to 1,197) was amplified by means of PCR in a 50 $\mu$ reaction containing $5 \mu \mathrm{l}$ of extracted DNA, $10 \mathrm{mM}$ Tris- $\mathrm{HCl}, 1.5 \mathrm{mM} \mathrm{MgCl}$, $50 \mathrm{mM} \mathrm{KCl}, 0.2 \mathrm{mM}$ of each dNTPs, $0.3 \mu \mathrm{M}$ of primers P1F and $\mathrm{PR}^{25}$, and 1.25 units of Taq Polymerase (Roche Diagnostics GmbH, Mannheim, Germany). Forty cycles of amplification were performed under these conditions: denaturation at $94^{\circ} \mathrm{C}$ for 30 seconds, annealing at $50^{\circ} \mathrm{C}$ for 30 seconds and elongation at $72^{\circ} \mathrm{C}$ for 2 minutes. For some samples that did not produce successful amplification, nested PCR was performed using $2 \mu \mathrm{l}$ of the first $\mathrm{PCR}$ product, i.e. primers $\mathrm{P} 4 \mathrm{~F}$ and $\mathrm{PR} 2$ (positions 230 to 1,017$)^{25}$, under the same thermal profile, except for annealing $\left(55^{\circ} \mathrm{C}\right.$ for 30 seconds). The PCR products were analyzed by means of electrophoresis on agarose gel $(1 \% \mathrm{w} / \mathrm{v})$.

\section{Sequencing}

PCR product purification was performed using the QIAquick PCR Purification Kit (QIAGEN GmbH, Hilden, Germany), in accordance with the manufacturer's instructions. Part of the polymerase gene (including the YMDD motif) was sequenced by using the BigDye $\mathrm{T}^{\mathrm{TM}}$ Cycle Sequencing kit, v. 3.1 (Applied Biosystems, Foster City, CA, USA) in a $20 \mu \mathrm{l}$ reaction containing $2 \mu \mathrm{l}$ of the BigDye reagent, 10 to 40ng of purified PCR DNA, $3.2 \mathrm{pmol}$ of primer and deionized water. The thermal cycles were: $96^{\circ} \mathrm{C}$ for 10 seconds, for denaturation; $50^{\circ} \mathrm{C}$ for 30 seconds, for annealing; and $60^{\circ} \mathrm{C}$ for 4 minutes, for elongation. The reaction was carried out over 35 cycles and was analyzed by means of the automatic sequencer ABI 3,100 (Applied Biosystems).

\section{Determination of viral genotype by phylogenetic analysis}

After sequencing of the samples, nucleotide sequences were analyzed and edited using Seqman $^{\text {Tx }}$ (DNASTAR, Inc. Madison, WI, USA). The edited sequences (GenBank databases accession numbers, HBV0001: EU221426; HBV0002: EU221427; HBV0003: EU221428; HBV0004:EU221429; HBV0006: EU221430; HBV0007: EU221431; HBV0008: EU221432; HBV0009: EU221433; HBV0010: EU221434; HBV0011: EU221435; HBV0014:EU221436; HBV0016: EU221437; HBV0018: EU221438; HBV0019: EU221439; HBV0020: EU221440; HBV0024: EU221441; HBV0025: EU221442; HBV0026: EU221443; HBV0029: EU221444; HBV0030: EU221445; HBV0031:EU221446; HBV0032: EU221447; HBV0033: EU221448; HBV0034: EU221449; HBV0036: EU221450; HBV0037: EU221451; HBV0038: EU221452; HBV0039: EU221453; HBV0040: EU221454; HBV0041: EU22 1455; HBV0042: EU221456; HBV0045: EU221457; HBV0047: EU221458; HBV0048: EU221459; HBV0050: EU221460; HBV0051: EU221461; HBV0052: EU221462; HBV0053: EU221463; HBV0055: EU221464; HBV0056: EU221465; HBV0057: EU221466; HBV0058: EU221467; HBV0059: EU221468; HBV0061: EU221469; HBV0062: EU221470; HBV0064: EU221471; HBV0065: EU221472; HBV0066: EU221473; HBV0068: EU221474; HBV0069: EU221475) were aligned with 20 reference sequences 
that included all genotypes, which were obtained from GenBank (accession numbers for Genotype A: Z35717; X51970; M57663. Genotype B: D50521; X97851; M54923. Genotype C: D23682; D50517; X75665. Genotype D: M32138; X97849; X65257. Genotype E: X75664; X75667. Genotype F: AB036910; X75663; X69798. Genotype G: AB056515; AB064313; AF160501) using MegAlign $^{\text {TM }}$ (DNASTAR). The sequence of the woolly monkey HBV (WMHBV, accession number AF046996) was used as an out-group to root the phylogenetic tree. The distance matrix was constructed using the DNADIST program, and the phylogenetic analysis was done using a neighbor-joining method. The Kimura-2-parameter substitution model was run using the neighbor-joining program. Bootstrapping was performed with 1,000 replicates using the Seqboot program to assess the robustness of the tree. Finally, phylogenetic trees were built using the Treeview 1.4 program. DNADIST, Neighbor-joining, Seqboot and Treeview 1.4 are programs within the PHYLIP package, version $3.5 \mathrm{c}^{26}$. Statistical analysis (Fisher's exact test) was performed to observe the relationship between mutations and genotypes.

\section{Ethical}

This study was approved by the Ethics Committee of Hospital das Clínicas de Ribeirão Preto and informed consent was obtained from all patients.

\section{RESULTS}

\section{Genotyping}

The PCR products from the samples were sequenced and phylogenetic analysis (Figure 1) was performed on the 50 sequences using the neighbor-joining method. It was found that 29 (58\%) patients were infected with HBV genotype D, 20 (40\%) with HBV genotype A and one (2\%) with HBV genotype F.

\section{YMDD motif variants}

Deduced amino acid sequences were obtained in order to detect the lamivudine resistance substitutions in the YMDD motif. Among the four lamivudine-resistant samples of genotype A, all of them presented YVDD variants, and among the samples of the genotype $\mathrm{D}$, four $(50 \%)$ presented YVDD variants and four $(50 \%)$ presented YIDD variants. All samples that presented YVDD variants, regardless of the genotype, also presented another substitution at amino acid position 180 (L180M).

\section{YMDD variants and HBV genotype}

Although the statistical analysis did not show significant results, our sequence analyses showed that substitutions in the YMDD motif appeared in $20 \%$ (4/20) of the samples of genotype A and in approximately $27.6 \%(8 / 29)$ of the samples of genotype $\mathrm{D}$. These observations denote that the likelihood that YMDD substitution presenting resistance to lamivudine might appear was approximately $37.9 \%$ higher in patients with genotype $\mathrm{D}$ than in those with genotype $\mathrm{A}$.

\section{DISCUSSION}

Hepadnaviruses are the only DNA viruses that, similar to retroviruses, utilize a reverse transcription step in the replication of the viral genome. Reverse transcription is an error-prone process ${ }^{27}$ and, similar to what happens with human immunodeficiency virus (HIV) and human T-cell leukemia virus (HTLV), this process results

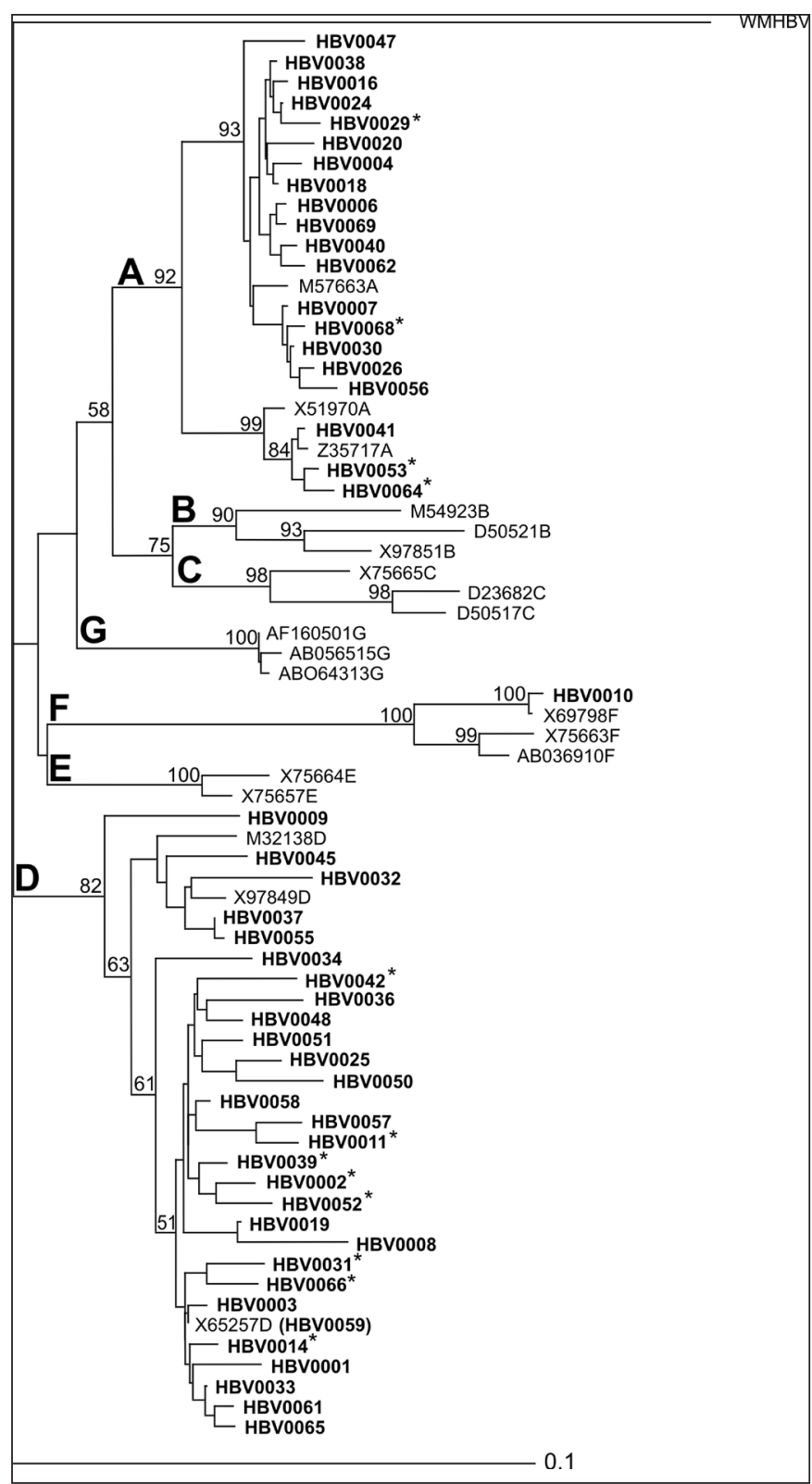

FIGURE 1 - Phylogenetic tree with part of the $\mathrm{HBV}$ polymerase gene sequences (from nucleotide 519 to 997) of patients with HBV (sample sequence names are those initiated with $\mathrm{HBV}$ followed by the sample number) and reference sequences of human genotypes $A$ to $G$ obtained from GenBank, indicated by the accession number, followed by the respective genotype. Neighbor-joining bootstrap values and genotypes are indicated on branches and the tree was rooted with the WMHBV sequence. ${ }^{*}$ Sequences with mutation in YMDD motif.

in the appearance of HBV subpopulations known as quasispecies. These contain nucleotide substitutions within the viral genome in infected individuals ${ }^{28}$. The frequency of HBV mutations has been estimated to be approximately 1.4 to $3.2 \times 10^{-5} \mathrm{nt}$ substitutions per site per year, which is about ten times higher than the rates for other DNA viruses. The magnitude and rate of virus replication are also important in the process of mutation generation ${ }^{29}$. Mutations may lead some variants to escape the immunological defense system ${ }^{30}$, antiviral treatment ${ }^{31}$ or vaccine protection ${ }^{32}$. In the case of HBV, reverse transcription is carried out through viral polymerase. Substitutions in domain C, especially in the YMDD motif, lead to resistance to lamivudine treatment ${ }^{33}$.

In the present study, twelve samples presented these substitutions. Eight of these samples presented a YVDD variant (M204V) and four 
presented a YIDD variant (M204I). These results are concordant with other studies that described YVDD as the most frequent variant, followed by the YIDD variant ${ }^{8}$. Moreover, our samples with M204V substitution were always in combination with the mutation L180M, while the samples with M204I substitution were not. These data are concordant with other studies that reported that the substitution M204V develops in combination with the substitution L180M, whereas the substitution M204I usually emerges alone ${ }^{14,34}$. Data from in vitro studies have shown that M204V substitution alone confers less resistance than the M204I substitution, which might explain the fact that M204V and L180M substitutions usually occur in association. Thus, this association may occur in vivo to improve replication fitness in the presence of lamivudine ${ }^{14,35}$. Studies on the biological behavior of the resistant mutant strains in cell cultures have shown that the replication rate of both variants, M204V and M204I, is much lower than that of the wild HBV. Moreover, further studies suggest that restoration of the replication rate occurs with the addition of the L180M mutation, which we also observed ${ }^{36,37}$.

These resistant variants may appear after six months of lamivudine therapy ${ }^{38}$, but the likelihood that resistance may appear possibly increases with longer periods of treatment ${ }^{12}$. In the present study, only $16.7 \%(2 / 12)$ of the cases presented substitutions related to lamivudine resistance during the first year of treatment (data not shown).

Genotype distribution studies on HBV in Brazil are rare, and the number of strains analyzed is still insufficient for better understanding of genotype distribution in this country $y^{21,22}$. Data from other studies indicate that genotypes A, D and F are present in Brazil ${ }^{19,20}$. In our study, we observed the presence of these genotypes. Although our data differ in genotype distribution, in relation to data from other regions in Brazil, these results are concordant with another study reported by Resende et $\mathrm{a}^{39}$ from the same region, where genotype $\mathrm{D}$ is the most prevalent followed by genotypes $\mathrm{A}$ and $\mathrm{F}$.

Few studies have been carried out in order to establish relatedness between resistance to lamivudine treatment and HBV genotype. In a study on patients infected with $\mathrm{HBV}$ of genotypes $\mathrm{B}$ and $\mathrm{C}, \mathrm{Kao}^{40}$ did not observe any differences in the likelihood of development of resistance to lamivudine. On the other hand, Pan et al ${ }^{41}$ showed that although there are no differences between these HBV genotypes and resistance to lamivudine, the likelihood that the YVDD variant might emerge was higher with genotype $B$ than with genotype $C$. In a study on patients infected with $\mathrm{HBV}$ of genotypes A, B and C, Akuta et al ${ }^{11}$ suggested that resistance to lamivudine was not genotype-dependent. However, in the same study, patients infected with one subgroup of genotype $\mathrm{B}(\mathrm{Ba})$, named the Asiatic subgroup, presented emergence of a significantly higher rate of resistance than observed in another genotype $B(B j)$ subgroup, named the Japan subgroup. Zöllner et $\mathrm{al}^{13}$ showed the existence of differences in mutational profile during the lamivudine resistance selection between genotypes $\mathrm{A}$ and $\mathrm{D}$, but did not show the possibility that these genotypes might develop resistant variants at different rates. Other recent studies have suggested that the rate of lamivudine resistance was higher among patients infected with $\mathrm{HBV}$ genotype $\mathrm{A}$ than among those with genotype $\mathrm{D}^{42,43}$.

In Brazil, some studies have observed this relationship ${ }^{23}$ but, like in the present study, the number of samples was insufficient to correlate lamivudine resistance mutations and genotype. Studies with large number of samples need to be performed in order to clarify the role of $\mathrm{HBV}$ genotype and treatment response. Although $20 \mathrm{HBV}$ samples were collected from patients that showed resistance to treatment with lamivudine, only 12 samples showed substitution in the YMDD motif. Some of the patients did not follow the physician's recommendations and did not take lamivudine accordingly. Furthermore, we detected, in one of the patients, a mutation in the YMDD motif before the beginning of the lamivudine treatment. This patient did not return and therefore no follow-up specimens were obtained. Despite the low number of samples, our results show a difference in the rate of appearance of resistance-related substitutions. The appearance of mutations in HBV cases was 1.38 times more frequent in genotype $\mathrm{D}$ than in genotype $\mathrm{A}$. There is an essential need to continue investigating this relatedness with a larger number of samples, in order to confirm our results.

\section{CONFLICT OF INTEREST}

The authors declare that there is no conflict of interest.

FINANCIAL SUPPORT

FCFRP-USP, CAPES

\section{REFERENCES}

1. Alter MJ. Epidemiology and prevention of hepatitis B. Semin Liver Dis 2003; 23:39-46.

2. Zoulim F. Mechanism of viral persistence and resistance to nucleoside and nucleotide analogs in chronic Hepatitis B virus infection. Antiviral Res 2004; 64:1-5.

3. Lacey L. Review of economic benefits of treating chronic hepatitis B with lamivudine. J Gastroenterol Hepatol 2004; 19:S10-12.

4. Tiollais P, Pourcel C, Dejean A. The hepatitis B virus. Nature 1985; 317:489 495.

5. Mutimer D. Hepatitis B virus infection: resistance to antiviral agents. J Clin Virol $2001 ; 21: 239-242$.

6. Wright TL. Clinical Trial Results and Treatment Resistance with lamivudine in hepatitis B. Semin Liver Dis 2004; 24:31-36.

7. Lok ASF, McMahon BJ. Chronic hepatitis B. Hepatol 2001; 34:1225-1241.

8. Papatheodoridis GV, Dimou E, Papadimitropoulos V. Nucleoside analogues for chronic hepatitis B: antiviral efficacy and viral resistance. Am J Gastroenterol 2002; 97:1618-1628.

9. Perrilo RP. Overview of treatment of hepatitis B; Key approaches and clinical challenges. Semin Liver Dis 2004; 24:23-29.

10. Fischer KP, Gutfreund KS, Tyrrell DL. Lamivudine resistance in hepatitis B: mechanisms and clinical implications. Drug Resist Updat 2001; 4:118-128.

11. Akuta N, Suzuki F, Kobayashi M, Tsubota A, Suziki Y, Hosaka T, et al. The influence of hepatitis B genotype on the development of lamivudine resistance during long-term treatment. J Hepatol 2003; 38:315-321.

12. Suzuki F, Tsubota A, Arase Y, Suzuki Y, Akuta N, Hosaka T, et al. Efficacy of lamivudine therapy and factors associated with emergence of resistance in chronic hepatitis b virus infection in Japan. Intervirol 2003; 46:182-189.

13. Zöllner B, Petersen J, Puchhammer-Stöckl E, Kletzmayr J, Sterneck M, Fischer L, et al. Viral Features of Lamivudine Resistant Hepatitis B Genotypes A and D. Hepatology 2004; 36:42-50.

14. Allen MI, Deslauriers M, Andrews CW, Tipples GA, Walters KA, Tyrrel DL, et al Identification and characterization of mutations in hepatitis B virus resistant to lamivudine. Lamivudine Clinical Investigation Group. Hepatol 1998; 27:16701677

15. Okamoto H, Tsuda F, Sakugawa H, Sastrosoewignjo R, Imai M, Miyakawa Y, et al. Typing hepatitis b virus by homology in nucleotide sequence. J Gen Virol $1988 ; 69: 2575-2583$ 
16. Norder H, Hammas B, Löfdahl S, Couroucé AM, Magnius LO. Comparison of the amino acid sequences of nine different serotypes of hepatitis B surface antigen and genomic classification of the corresponding hepatitis B virus strains. J Gen Virol 1992; 73:1201-1208.

17. Stuyver L, De Gendt S, Van Geyt C, Zoulim F, Fried M, Schinazi RF, Rossau R. A new genotype of hepatitis $B$ virus: complete genome and phylogenetic relatedness. J Gen Virol 2000; 81:67-74.

18. Arauz-Ruiz P, Norder H, Robertson BH, Magnius LO. Genotype H: a new Amerindian genotype of hepatitis B virus revealed in Central America. J Gen Virol 2002; 83:2059-2073.

19. Ribeiro NR, Campos GS, Angelo AL, Braga EL, Santana N, Gomes MM, et al. Distribution of hepatitis $\mathrm{B}$ virus genotype among patients with chronic infection. Liver Int 2006; 26:636-642.

20. Araujo MN, Melo FCA, Yoshida CFT, Niel C, Gomes SA. High proportion of subgroup A' (genotype A) among Brasilian isolates of Hepatitis B virus. Arch Virol 2004; 149:1383-1395.

21. Niel C, Moraes MTB, Gaspar AMC, Yoshida CFT, Gomes AS. Genetic diversity of hepatitis b virus strains isolated in Rio de Janeiro, Brazil. J Med Virol 1994; 44:180-186.

22. Moraes MTB, Gomes SA, Niel C. Sequence analysis of pre S/S gene of hepatitis B virus strains of genotype A, D and F isolated in Brazil. Arch Virol 1996; 141:17671773 .

23. Bottecchia M, Souto FJ, O KM, Amendola M, Brandão CE, Niel C, et al. Hepatitis $\mathrm{B}$ virus genotypes and resistance mutations in patients under long term lamivudine therapy: characterization of genotype G in Brazil. BMC Microbiol 2008; 8:11.

24. Oliveira CM, Farias IP, Ferraz da Fonseca JC, Brasil LM, de Souza R, et al. Phylogeny and molecular genetic parameters of different stages of hepatitis $\mathrm{B}$ virus infection in patients from the Brazilian Amazon. Arch Virol 2008; 153:823830.

25. Ahmed SNS, Tavan D, Pichoud C, Berby F, Stuyver L, Johnson M, et al. Early detection of viral resistance by determination of hepatitis $\mathrm{B}$ virus polymerase mutations in patients treated by Lamivudine for chronic hepatitis B. Hepatol 2000; 32:1078-1088.

26. Felsenstein J. PHYLIP (Phylogeny Inference Package). Distributed by the author. Department of Genetics, The University of Washington, Seattle, WA; 1993; v. $3.5 \mathrm{c}$.

27. Domingo E, Holland JJ. RNA virus mutations and fitness for survival. Annu Rev Microbiol 1997; 51:151-178.

28. Torresi J. The Virological and clinical significance of mutations in the overlapping envelope and polymerase genes of hepatitis B virus. J Clin Virol 2002; 25:97106.

29. Locarnini S. Molecular virology of hepatitis B virus. Semin Liver Dis 2004; 24:S3-10.

30. Farci P, Shimoda A, Wong D, Cabezon T, De Giovannis D, Strazzera A, et al. Prevention of hepatitis $C$ virus infection in chimpanzees by hyper-immune serum against the hypervariable region 1 of the envelope 2 protein. Proc Natl Acad Sci USA 1996; 93:15394-15399.

31. Kirishima T, Okanoue T, Daimon Y, Itoh Y, Nakamura H, Morita A, et al. Detection of YMDD mutant using a novel sensitive method in chronic liver disease type B patients before and during lamivudine treatment.J Hepatol 2002; 37:259-265.

32. Carman WF, Zanetti AR, Karayiannis P, Waters J, Manzillo G, Tanzi E, et al. Vaccine-induced escape mutant of hepatitis B virus. Lancet 1990; 336:325329.

33. Chen WN, Oon CJ. Hepatitis B virus mutants: An overview. J Gastroenterol Hepatol 2002; 17:497-499.

34. Lok AS, Hussain M, Cursano C, Margotti M, Gramenzi A, Grazi GL, et al. Evolution of hepatitis B virus polymerase gene mutations in hepatitis B e antigen-negative patients receiving lamivudine therapy. Hepatol 2000; 32: 1172-1174.

35. Ono-Nita SK, Kato N, Shiratori Y, Lan KH, Yoshida H, Carrilho FJ, et al. Susceptibility of lamivudine-resistant hepatitis B virus to the other reverse transcriptase inhibitors. J Clin Invest 1999; 103:1635-1640.
36. Melegari M, Scaglioni PP, Wands JR. Hepatitis b virus mutants associated with $3 \mathrm{TC}$ and fanciclovir administration are replication defective. Hepatol 1998; 27:628-633.

37. Ono-Nita SK, Kato N, Shiratori Y, Masaki T, Lan KH, Carrilho FJ, et al. YMDD motif in hepatitis b virus DNA polymerase influences on replication and lamivudine resistance: a study by in vitro full-length viral DNA transfection. Hepatol 1999; 29:939-945.

38. Chayama K, Suzuki Y, Kobayashi M, Kobayashi M, Tsubota A, Hashimoto M, et al. Emergence and takeover of YMDD motif mutant hepatitis B virus during long therapy and re-takeover by wild-type after cessation of therapy. Hepatol 1998; 27:1711-1716

39. Rezende RE, Fonseca BA, Ramalho LN, Zucoloto S, Pinho JR, Bertolini DA, et al. The precore mutation is associated with severity of liver damage in Brazilian patients with chronic hepatitis B. J Clin Virol 2005; 32:53-59.

40. Kao JH. Clinical relevance of hepatitis B genotypes: A case of déjà vu? J Gastroenterol Hepatol 2002; 17:113-115.

41. Pan XP, Li LJ, Du WB, Li MW, Cao HC, Sheng JF. Differences of YMDD mutational patterns, precore/core promoter mutations, serum HBV DNA levels in lamivudine resistant hepatitis B genotypes B and C.J Viral Hepat 2007; 14:767-74

42. Kobayashi M, Suzuki F, Akuta N, Suzuki Y, Arase Y, Ikeda K, et al. Response to long-term lamivudine treatment in patients infected with hepatitis $\mathrm{B}$ virus genotypes A, B, and C. J Med Virol 2006; 78:1276-1283.

43. Orito E, Fujiwara K, Tanaka Y, Yuen MF, Lai CL, Kato T, et al. A case-control study of response to lamivudine therapy for 2 years in Japanese and Chinese patients chronically infected with hepatitis $\mathrm{B}$ virus of genotypes $\mathrm{Bj}, \mathrm{Ba}$ and $\mathrm{C}$. Hepatol Res 2006; 35:127-134. 